\title{
Tonal Polarity as Phonologically Conditioned Allomorphy in Mundurukú
}

\author{
GESSIANE PICANÇO \\ University of British Columbia, Canada/Museu Paraense Emilio Goeldi, Brazil
}

\section{Introduction}

The notion of tonal polarity refers to a phenomenon where a morpheme is assigned a tone opposite to an adjacent tone. At issue is whether polarization equals dissimilation. Schuh (1978) and Newman (1995) propose that morphemes may be polar by nature; i.e. their surface tone is determined exclusively by the context in which they occur. If there exists evidence to presume that these morphemes have an underlying tone, then the process is one of dissimilation. For example, in the Guddiri dialect of Hausa, the diminutive dan (masc.) shows polarity: dán ráagó 'a small ram'/dàn yáaroo 'a small boy'. However, the fact that the diminutive exists in the language as an independent (H-tone) noun dán 'son' suggests that this is a case of dissimilation rather than true tonal polarity (Newman 1995; Schuh 1978). At another extreme, Kenstowicz, Nikiema, and Ourso (1988) propose that polar tones are underlyingly $\mathrm{H}$ in all languages and the apparent polarity is in fact the result of dissimilatory rules. Pulleyblank's (1986) analysis of tonal polarity in Margi treats polarizing morphemes as having floating $\mathrm{H}$ tone underlyingly, but they are lexically marked as extratonal. Extratonality in conjunction with a rule of $\mathrm{H}$-deletion generates the polarity effect. A more recent, constraint-based account has been proposed by Suzuki (1998). Tonal polarity is a dissimilatory process that results from the requirements of two Generalized OCP constraints - one prohibits a sequence of $\mathrm{H}$-tones, $\left({ }^{*} \mathrm{H} \ldots \mathrm{H}\right)$, while the other prohibits a sequence of L-tones, $\left({ }^{*} \mathrm{~L} . . . \mathrm{L}\right)$, in a given domain.

The question "true tonal polarity or dissimilation?" seems far from having a definitive answer and I will not pursue it here. Tonal polarity, although common in tone languages, is never a general phonological rule; only few items, mostly affixes, participate in this process. In this paper, 1 examine tonal polarity in Mundurukú, a Tupi language spoken in Brazil. Mundurukú contains a set of nouns that show polarity in a particular context, but $L$ otherwise. After examining its properties, I propose that the phenomenon is best captured in terms of phonologically conditioned allomorphy (Kiparsky 1994). My proposal asserts that 
Optimality Theory (Prince \& Smolensky 1993) can properly account for the distribution of allomorphs. I will demonstrate that selection of morpheme variants is determined by PARSE-MORPH (Akinlabi 1996), and that Alignment constraints (McCarthy \& Prince 1993) and constraint conjunction (Crowhurst \& Hewitt 1997) are required to ensure that allomorphs are selected according to their appropriate environments. Finally I will compare the analysis with that advocated in Suzuki (1998), and show that the allomorphy approach is to be preferred because it successfully explains tonal polarity as well as other tonal processes observed in Mundurukú.

\section{Tonal polarity in Mundurukú}

Every vowel in Munduruku has either high or low tone on the surface. At the underlying level, however, there is a three-way contrast, $/ \mathrm{H}, \mathrm{L}, \varnothing /$ (Picanço 2002). ${ }^{l}$ Mundurukú contains a small number of inalienable nouns that surface on a tone opposite to that of an adjacent syllable. Tonal polarity exhibits certain properties, as described below.

\subsection{Tonal polarity is idiosyncratic}

Mundurukú monosyllabic inalienable nouns may be divided into two basic tonal groups: nouns that have $\mathrm{L}$ tone and those that show tonal polarity. ${ }^{2}$ For instance, top 'leaf/CLS', toy 'tooth', and $? a$ 'head/CLS' are H following L and L following $\mathrm{H}$, as shown in $(1-3)$.
(a) ákò dáp 'banana leaf' banana leaf/CLS
(b) bórọ dàp 'cotton leaf' cotton leaf/CLS
(a) ò-nọy 'my teeth' 1sg-tooth
(b) òcé-nòy our teeth' 1pl.excl.-tooth
(a) tópà-?á 'his/her forehead' face-CLS
(b) witá-?à 'stone' stone-CLS

They differ from the other group, which is always L-toned.

\footnotetext{
'Abbreviations: $\mathrm{CLS}=$ classifier; $\mathrm{NOM}=$ nominalization; $\mathrm{DIM}=$ diminutive; $\mathrm{RED}=$ reduplication; $\mathrm{pl}=$ plural; $\mathrm{sg}=$ singular; excl=exclusive; $\hat{v}=$ high tone; $\hat{v}=$ low tone; $\gamma=$ nasality; $v=$ laryngealization.

${ }^{2}$ There are few inalienable nouns that seem to have H-tone: $-k \dot{a}$ 'cultivated field' and $-c o$ 'basket'.
} 

(a) pà 'arm/CLS' $\rightarrow$ ò-bà $\quad$ 'my arm'
lsg-arm
òcé-bà 'our arms'
Ipl.excl.-arm
(b) è̀n 'flesh' $\rightarrow$ biò èn 'tapir's flesh'
tapir-flesh
sàpòkáy èn 'hen's flesh'
hen-flesh

\subsection{Tonal polarity is peripheral}

Pulleyblank (1986:214) observes that "polarity effects occur at the edges of a Jomain." (See also Archangeli \& Pulleyblank (1994).) Mundurukú confirms the assumption that tonal polarity is peripheral. Many of the inalienable nouns can incorporate to the verb, as the subject in the case of intransitive or descriptive verbs and as the object in the case of transitive verbs (Gonçalves 1987), or be combined to form compounds. When attached to the verb, polarizing nouns appear in preverbal position where they do not manifest tonal polarity, surfacing L toned by default; for instance, top 'leaf/CLS' in (5).
(a) ò-t’̀p-cócó 'I saw a leaf' 1sg-leaf-see.RED
(b) tə̀p-bòn át tàp 'big leaf' leaf-be.big NOM leaf

Similarly, in combinations of two or more polar nouns, only the rightmost element polarizes while the preceding ones surface $L$ toned. As seen in (6a), -ba 'finger/CLS' occurs at the right periphery where it is $\mathrm{H}$ following the possessive prefix $o$ - ' $1 \mathrm{sg}$ '; if another morpheme is added, for example - na 'nail' in (6b), -bo surfaces $\mathrm{L}$ and $-n a$ $\mathrm{H}$. The polarity effect is blocked by -?it'?it 'Diminutive' in (6c), causing $-n$ ą to surface $L$.
(a) ò-bá lsg-finger/CLS
(b) ò-bà̀-nọ 1sg-finger/CLS-nail
(c) ò-bə̀-nò-Pُit?í 'my little fingernail' 1sg-finger-nail-DIM

$$
\begin{aligned}
& \text { 'my finger' } \\
& \text { 'my fingernail' } \\
& \text { 'my little fingernail' }
\end{aligned}
$$

The important generalizations are: (i) tonal polarity affects a small number of morpinemes, (ii) which surface $\mathrm{H}$ only at the right periphery of a given domain, but (iii) L otherwise. I will refer to the domain where tonal polarity shows up as being the phonological word (PhWd), which is defined here as the domain that coincides with morphosyntactic boundaries within which phonological processes 
apply (Hall 1997). The examples below illustrate polarization in two contexts. In (7a), top occurs within the word as a classifier (leaf-like object); in (7b), it is the head of a noun phrase. For present purposes, I assume that either construction may constitute a phonological word.
(a) îwáp-tə̀p ' ray' wèrè-də́p 'mushroom'
(b) bóró dòp 'cotton leaf' ákò dóp 'banana leaf'

\subsection{Tonal polarity does not distinguish between underlying and derived tones}

Tonal polarity does not function as a general phonological rule. First, it applies only to a subset of inalienable nouns; i.e. it is morpheme-specific. The phenomenon must be distinguished from another, more general process, involving dissimilation of $\mathrm{L}$ tones. Lexical L-tones trigger dissimilation of a following $\mathrm{L}$, changing it to $\mathrm{H}$, to satisfy the Obligatory Contour Principle (Leben 1973; Goldsmith 1976; McCarthy 1986; Odden 1986). This is illustrated in (8b). Derived $\mathrm{L}$ tones are inert as triggers, as shown in (8a).
(a) ako-pa $\rightarrow$ ákòbà $\quad$ 'banana' $\begin{array}{ll}\text { I } & \text { I } \\ \mathrm{H} & \mathrm{L}\end{array}$
(b) waje-pa $\rightarrow$ wajèbá 'cacao'

Conversely, polarization does not distinguish between lexical and derived tones. For example, top 'leaf/CLS' is H following not only lexical L-tones ( $9 \mathrm{~b}$ ) but also derived ones $(9 \mathrm{a}){ }^{3}$

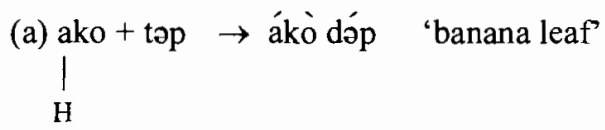

(a) ako + top $\rightarrow$ ákò dóp 'banana leaf'

H

\footnotetext{
${ }^{3}$ Newman (1995) reports that in Standard Hausa the 'stabilizer' nee/cee shows polarity whether or not the preceding word has tonal variants.
(a) jàakỉ nèe
'it's a donkey'
(b) riigáa cèe
'it's a gown'
(c) kèekè née $=$ kèeké(e) nèe
'it's a bicycle'

Similar pattern is found in Margi as well (Pulleyblank 1986; Hoffmann 1963).
} 
(b) waje ${ }_{L}+$ təp $\rightarrow$ wàjè dóp 'cacao leaf'

\subsection{Tonal polarity does follow from general patterns}

The general pattern in Mundurukú is that sequences of H-tones originating from distinct morphemes require no strategy to repair the OCP violation, as (10) illustrates. Despite this, we can assume that the OCP still plays a significant role in Mundurukú though in a more restrictive way.

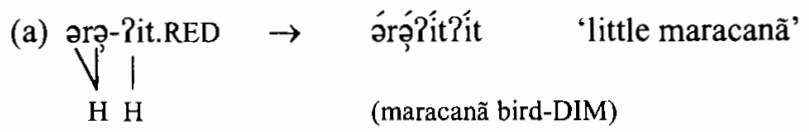

The core properties of tonal polarity in Mundurukú inalienable nouns are summarized below.

(11) Tonal polarity in Mundurukú

(a) It is idiosyncratic (i.e. morpheme-specific), applying only to nouns that are marked to undergo it.

(b) It is peripheral; i.e, it is restricted to the right edge of $\mathrm{PhWd}$.

(c) It does not distinguish between lexical and derived tones.

(d) It does not follow from general constraints which tones are or are not subject to in the language.

\section{Tonal polarity as phonologically-conditioned allomorphy}

We have seen that Mundurukú tonal polarity applies arbitrarily to a small group of nouns rather than applying as a general phonological rule. Besides, these nouns manifest polarity in a particular context, surfacing $L$ otherwise. The distribution of polarizing nouns in Mundurukú could be stated as follows: "the H-tone variant occurs at the right edge of PhWd, after L; the L-tone variant occurs elsewhere". Statements like this describe often-cited cases of phoneme variants (allophones) in Phonology or morpheme variants (allomorphs) in Morphology. Dealing with tonal polarity or similar phenomena as allomorphy may be a plausible alternative. I will here explore this possibility, asserting that Mundurukú tonal polarity is the result of phonologically-conditioned allomorphy.

\subsection{Selection of allomorphs}

Kiparsky (1994), who adopts the selection method advocated in Lieber (1982) and Zwicky (1986), argues for a model where allomorphs are lexical items with one unmarked, default alternant, and other, lexically marked, that is restricted to appropriate contexts. He characterizes the factors that condition allomorphy in terms of contextual or internal selection. Contextual selection may be either 
morpholexical (e.g. oxen), or phonological because "just as a 'morpheme' can be restricted to a particular phonological environment, so can an 'allomorph'."[p.17].

I will adopt Kiparsky's contextual phonological selection to account for the distribution of polarizing nouns in Mundurukú by arguing that these nouns have two input forms - one is toneless and the other is $\mathrm{H}$-toned, illustrated in (12) which must obey conditions imposed by the phonology in order to be realized. The specific/marked case is the H-tone variant, which must be selected only to the right edge of $\mathrm{PhWd}$, after $\mathrm{L}$. The toneless form is the general/unmarked case, occurring elsewhere.

$$
\begin{aligned}
& \text { leaf/CLS }=\{\text { táp, təp }\} \\
& \text { finger/CLS }=\{\text { pó[?], pə[?] }\}^{4}
\end{aligned}
$$

The relationship between the general case and the specific case is expressed by a dominance relation. In optimality-theoretic terms, allomorphs are ranked with respect to one another (Kager 1996). By analogy with the Pãnini's Theorem on Constraint-ranking (Prince \& Smolensky 1993), I suggest that if the specific and general allomorphs are in conflict, then the more specific must dominate the more general case, as in (13). The factors that will determine which allomorph must be taken to be more specific or more general are language-specific products. ${ }^{5}$

$$
\text { tóp } \gg \text { təp }
$$

The question then is how the selection of allomorphs should be handled by a constraint-based approach such as the Optimality Theory. The distribution of allomorphs, if phonologically conditioned, cannot be unrestricted; on the contrary, it must be accomplished by universal considerations. Viewed in this way, allomorphs, like features or featural affixes, need to be licensed to be phonetically realized. Their surface realization depends upon the restrictions imposed by the phonology to, generally, the more specific case. If such conditions are not satisfied, then the general case must occur instead.

I hypothesize that it is imperative to ensure that input forms of morpheme variants are realized in the output. This requirement is compelled by a family of constraints, namely PARSE-MORPH (Akinlabi 1996: 247), formally defined below, with particular formulations in (15).

PARSE-MORPH - A morph must be realized in the output.

\footnotetext{
${ }^{4}$ Mundurukú has a process of laryngealization in which certain morphemes trigger laryngealization on the preceding vowel under certain circumstances. For purpose of this study, I will distinguish this process by using [?] in the underlying form of the morpheme.

${ }^{5}$ See Hargus (2000) for a different proposal. According to her, the preferred allomorph is always the phonologically shortest variant, which is selected by a universal constraint called BREVITY.
} 
(a) PARSE-tóp - tóp must be realized in the output.

(b) PARSE-təp - top must be realized in the output.

Ranking of PARSE-MORPH constraints must reflect dominance relations between allomorphs. Thus, the H-tone variant, e.g. PARSE-táp, dominates the toneless varaint, e.g. PARSE -təp, in Mundurukú.

(16) PARSE -táp $\gg$ PARSE -təp

The tableau in (17) shows selection of the more specific over the general case.

(17) Selection of the specific case: PARSE -tóp >> PARSE -təp

\begin{tabular}{|l|c|c|c|}
\hline $\begin{array}{l}\text { ako }\left\{\begin{array}{l}\text { təp; təp }\} \\
\mathrm{H} \quad \mathrm{I}\end{array}\right. \\
\mathrm{H}\end{array}$ & $\begin{array}{c}\text { MaX } \\
\text { PATHH }\end{array}$ & $\begin{array}{c}\text { PARSE- } \\
\text { táp }\end{array}$ & $\begin{array}{c}\text { PARSE- } \\
\text { təp }\end{array}$ \\
\hline a) ákó dáp & & & $*$ \\
\hline b) ákò də̀p & & $* !$ & \\
\hline c) àkó də̀p & $* !$ & $*$ & \\
\hline
\end{tabular}

The domination relation PARSE-tóp >> PARSE-təop says that the H-tone allomorph must be selected first, as seen in the optimal candidate (17a). Candidate $(17 \mathrm{~b})$ is penalized by selecting the unmarked allomorph instead. MAXPATHH prohibits loss of tone specifications, eliminating candidate $(17 \mathrm{c}){ }^{6}$

The tableau in (17), however, does not show entirely how the restrictions on allomorph distribution are handled. There are two conditions on the distribution of the specific case in Mundurukú: (i) it is restricted to the right edge of PhWd; and (ii) it obeys the OCP constraint prohibiting a sequence of $\mathrm{H}$-tone $\left({ }^{*} \mathrm{HH}\right)$. The former is expressed here as an Alignment constraint (McCarthy \& Prince 1993) demanding coincidence of a $\mathrm{H}$-tone allomorph with the right edge of $\mathrm{PhWd}$.

(18) ALIGN-táp - ALIGN (tóp, Right, PhWd, Right)

táp must be aligned with the right edge of a phonological word

While PARSE-tóp demands the realization of táp in the output, ALIGN-tóp limits its occurrence at a given edge. This is illustrated in the following tableau. ALIGN must dominate PARSE in order to ensure that the specific case does not surface if it is not aligned with the right edge of PhWd.

\footnotetext{
${ }^{6} \mathrm{MAXPATHH}-\mathrm{Any}$ input path between $\mathrm{H}$ and an anchor must have a correspondent path in the output. (See Pulleyblank (1996))
} 
(19) Selection of the general case

\begin{tabular}{|c|c|c|c|c|}
\hline$\{$ təp; təp $\}$-bon at & $\begin{array}{c}\mathrm{MAX}_{\mathrm{AX}} \\
\mathrm{P}_{\mathrm{ATH}} \mathrm{H}\end{array}$ & $\begin{array}{l}\text { ALIGN- } \\
\text { tóp }\end{array}$ & $\begin{array}{l}\text { PARSE- } \\
\text { tóp }\end{array}$ & $\begin{array}{l}\text { PARSE- } \\
\text { top }\end{array}$ \\
\hline a) tápboy at & & $* !$ & 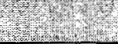 & 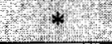 \\
\hline b) tòpbòn at & & & * & \\
\hline
\end{tabular}

Note, however, that ranking ALIGN-táp above PARSE-tóp does not prevent the specific case from being selected after a $\mathrm{H}$ tone, predicting, for example, *boro dóp instead of the actual form bóró dipp 'cotton leaf'. This is because there is an additional restriction on the distribution of the specific case in Munduruku, namely that it obeys the OCP constraint ${ }^{*} \mathrm{HH}$. To capture this requirement, suppose that PARSE is conjoined with the OCP constraint *HH. The proposal is not new, constraint conjunction (Smolensky 1997; Itô \& Mester 1996; Alderete 1997) has played an important role in accounting for phonological facts that could not be properly explained otherwise. Crowhurst \& Hewitt (1997) argue for a model of disjunction as positive conjunction where a candidate passes a conjunction if and only if it passes every conjunct. If a candidate fails to satisfy one of constraints from the conjunct, then it fails to satisfy the conjunct (cf. Smolensky 1997). Following Crowhurst \& Hewitt, I propose the following conjunction:

\section{(20) PARSE-táp ${ }^{\wedge} * \mathrm{HH}$}

PARSE-tóp requires the specific allomorph to be realized in the output, but this requirement is accomplished by the OCP constraint ${ }^{*} \mathrm{HH}$. The proposed conjunction achieves the correct results: it fails to select the H-tone allomorph when adjacent to a $\mathrm{H}$-tone base, and it captures the fact that only certain morphemes must obey ${ }^{*} \mathrm{HH}$. The candidates in $(21 \mathrm{a}, \mathrm{b})$ are non-optimal as both violate the conjunct. Candidate (21a) violates PARSE-tóp and (21b) violates ${ }^{*} \mathrm{HH}$. Since neither candidate passes the conjunction, they are evaluated by PARSE-tap which selects the default case instead.

(21) Selection of the general case

\begin{tabular}{|c|c|c|c|}
\hline $\begin{array}{c}\text { boro }\left\{\begin{array}{l}\text { təp; təp } \\
\mathrm{H} \quad \mathrm{H}\end{array}\right. \\
\text { a) bóró dóp }\end{array}$ & $\begin{array}{c}\text { ALIGN- } \\
\text { táp }\end{array}$ & PARSE-táp ${ }^{\wedge}{ }^{*} \mathrm{HH}$ & $\begin{array}{c}\text { PARSE- } \\
\text { təp }\end{array}$ \\
\hline b) bóró də́p & & $*$ & \\
\hline
\end{tabular}

When an input form contains two or more polarizing nouns, the hierarchy ALIGN $\gg$ PARSE-SC (specific case) $>>$ PARSE-GN (general case) predicts the 
attested results. Although PARSE-SC dominates PARSE-GC, no dominance relations can be established between one particular instantiation of PARSE-SC/ PARSE-GC and another instantiation of PARSE-SC/ PARSE-GC.

Consider, for instance, the case of $\dot{o}-b \partial \dot{\partial}-n a$ ' $^{\prime}$ my fingernail' in which both $-b \partial$ and $-n a$ are polar. We cannot say that constraints evaluating $p a ́$ dominate those evaluating nọ or vice-versa. Instead, let us assume that these constraints are left unranked. This is illustrated in the tableau in (22). Each set of allomorphs is evaluated by particular formulations of the general hierarchy, but no one is ranked over the other for the following noun. The specific case \{pó[?]\} cannot be selected in $(22 a, b)$ because it is not at the right edge of a phonological word. Candidates $(22 \mathrm{c}, \mathrm{d})$ both fail PARSE-pó, but $(22 \mathrm{c})$ is optimal because it satisfies the conjunction established for $\{$ nọ́[?]\}.

(22) Input: /o-\{pá[?];po[?]\}-\{nớ[?]; ną[?]\}/ $\rightarrow$ [òbə̀nó] 'my fingernail'

\begin{tabular}{|c|c|c|c|c|c|c|}
\hline Hierarchy: & \multicolumn{2}{|c|}{ ALIGN-SC } & \multicolumn{2}{|c|}{ PARSE-SC $\wedge *$ HH } & \multicolumn{2}{|c|}{ PARSE-GC } \\
\hline & $\begin{array}{c}\text { ALIGN- } \\
\text { pá }\end{array}$ & $\begin{array}{c}\text { ALIGN- } \\
\text { ná }\end{array}$ & $\begin{array}{l}\text { PARSE- }{ }^{\wedge} * \mathrm{HH} \\
\text { pá }\end{array}$ & $\begin{array}{l}\text { PARSE- }{ }^{\wedge} * \mathrm{HH} \\
\text { n’̧ }\end{array}$ & $\begin{array}{c}\text { PARSE- } \\
\text { pə }\end{array}$ & $\begin{array}{c}\text { PARSE- } \\
\text { n’̧ }\end{array}$ \\
\hline òbánว̀ & $* !$ & 12 & 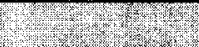 & P.) & $*$ & (x) \\
\hline òbáná & $* !$ & (1) & 4 & $*$ & * & 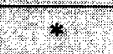 \\
\hline c) $\sigma$ òbə̀ná & & & * & & & * \\
\hline òbว̀nà & & & * & $* !$ & & ma \\
\hline
\end{tabular}

In this section I showed that Mundurukú tonal polarity can be analyzed as phonologically conditioned allomorphy. I proposed that rankings of allomorphs conforms the Pãnini's principle on constraint rankings - the more specific dominates the more general case. The selection of allomorphs is determined by PARSE-MORPH along with Alignment constraints and constraint conjunction. The interaction of these constraints handles the disjunctive pattern of allomorph distribution, selecting each variant to a context that is compatible with it.

\section{A comparison with the GOCP approach to tonal polarity.}

Suzuki (1998) claims that tonal polarity derives from the combination of two Generalized OCP (GOCP) constraints, given in (23).

(23) GOCP constraints (adapted from Suzuki 1998: 142)

$\left({ }^{*} \mathrm{H} \ldots \mathrm{H}\right)_{\text {Domain }}-\mathrm{A}$ sequence of $\mathrm{H}$-tone is prohibited within a given domain.

$\left({ }^{*} \mathrm{~L} \ldots \mathrm{L}\right)_{\text {Domain }}-\mathrm{A}$ sequence of $\mathrm{L}$-tone is prohibited within a given domain.

The GOCP approach makes wrong predictions in Mundurukú. First, we have seen that the OCP prohibits a sequence of L-tone, but only lexical L-tones trigger dissimilation of a following L (e.g. wajè-bá 'cacao' but ákò-bà 'banana'). This 
generalization is obscured in Suzuki's proposal, which predicts, for example, that the L-tone of -bã in [ákò-bà] 'banana' should be realized as $\mathrm{H}$.

(24) Mundurukú and the GOCP approcah

\begin{tabular}{|l|l|}
\hline áko + top & $\left({ }^{*} \mathrm{~L} . . \mathrm{L}\right) \quad\left({ }^{*} \mathrm{H} . . . \mathrm{H}\right)$ \\
\hline a) ákò dóp & \\
\hline b) ákò də̀p & $* !$ \\
\hline áko-pà & \\
\hline c) ákò-bá & \\
\hline d) $\odot$ ákò-bà & $* !$ \\
\hline
\end{tabular}

Second, it predicts tonal polarity everywhere and, as I showed, polarization is restricted to the right edge of a phonological word in Mundurukú. In other contexts, polarizing nouns get $\mathrm{L}$ by default. Take again the case of [ò-bè-nó] 'my fingernail'. Three candidates are listed in the tableau in (26). The GOCP constraints select (26a) over the actual output (26c).

(26) Sequences of polar morphemes

\begin{tabular}{|c|c|}
\hline$o+p \partial[?]+n \vartheta$ & $\left({ }^{*} \mathrm{~L} \ldots \mathrm{L}\right) \quad\left({ }^{*} \mathrm{H} \ldots \mathrm{H}\right)$ \\
\hline a) òbónà & \\
\hline b) : : òbə̃ná & $* !$ \\
\hline c) òbə̀nวิ & $* ! *$ \\
\hline
\end{tabular}

The analysis pursued thus far, on the other hand, provides not only a good account of tonal polarity in Mundurukú but also generalizes to other tonal processes observed in the language. For instance, the possessive prefix has two surface realizations: $e$ - in word-initial position, (27a); $\dot{e}$ - otherwise, (27b).
(a) àyácát é-kòbé
'woman's canoe' woman POSS-canoe
(b) w-è-kòbé 'my canoe' 1-POSS-canoe

Under the proposal presented here, the analysis of the possessive prefix is straightforward. The prefix has two allomorphs /e-; e-/ ranked as e- $>>$ e-. The specific allomorph, e-, must be left-aligned with a word. ALIGN-é- dominates PARSE-é-, which dominates PARSE-e-, yielding the ranking ALIGN-é- >> PARSE-é> PARSE-e-. The specific case shows no other restriction, consequently PARSE-erequires no conjunction with a markedness constraint. As shown in the following 
tableau, the same analysis proposed for polarizing nouns also accounts for the distribution of variant forms of the possessive prefix.

(28) Selection of $\{$ é-; e- $\}$

\begin{tabular}{|c|c|c|c|}
\hline$N\{\dot{e}-; e-\}-N$ & ALIGN-é- & PARSE-é- & PARSE-è- \\
\hline a) $\quad \mathrm{N}$ è-N & & $* !$ & \\
\hline b) $=\mathrm{Ne}-\mathrm{N}$ & & & * \\
\hline PREF- $\{\mathrm{e}-; \mathrm{e}-\}-\mathrm{N}$ & & & \\
\hline c) PREF-è-N & & * & \\
\hline d) PREF-é-N & $* !$ & 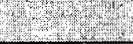 & $*$ \\
\hline
\end{tabular}

\section{Conclusion}

I argued that the generalizations involving tonal polarity in Mundurukú can be captured in terms of phonologically conditioned allomorphy. The marked allomorph is the $\mathrm{H}$-tone variant and is to be selected to an appropriate context; the default variant occurs elsewhere. I suggested that selection of allomorphs is determined by the PARSE-MORPH family of constraints demanding that each variant be realized in the output. Ranking of PARSE constraints conform that of allomorphs, namely the specific case must dominate the general case. The hierarchy ALIGN-SC $\gg$ PARSE-SC $>$ PARSE-GC not only successfully accounts for tonal polarity in Mundurukú - including sequences of polar morphemes - but also generalizes to other cases of allomorphy observed in the language.

\section{References}

Akinlabi, A. 1996. Featural affixation. Journal of Linguistics 32: 239-289. Alderete, John. 1997. Dissimilation as local conjunction. NELS 27: 17-31. Archangeli, D. \& D. Pulleyblank. 1994. Grounded Phonology. MIT Press.

Crowhurst, M. \& M. Hewitt. 1997. Boolean Operations and Constraint Interaction in Optimality Theory. ROA-229.

Goldsmith, J. 1976. Autosegmental Phonology. Garland Press.

Gonçalves, C.H. 1987. Concordância em Mundurukú. Editora da Unicamp, Campinas.

Hall, T.A. 1997. The phonological word: A review. In T. A. Hall \& U. Kleinhenz (eds.), Studies on the Phonological Word. John Benjamins Publishing Company.

Hargus, S. 2000. Prosodically Conditioned Allomorphy in Optimality Theory: Brevity in Witsuwit'en. Ms., University of Washington.

Hoffmann, C. 1963. A Grammar of the Margi Language. London: OUP.

Itô, J. \& A. Mester. 1996. Rendaku 1: Constraint Conjunction and the OCP. ROA-144. 
Kager, R. 1996. On affix allomorphy and syllable counting. In U. Kleinhenz (ed.), Interfaces in Phonology. Akademie Verlag.

Kenstowicz, M., E. Nikiema, \& M. Ourso. 1988. Tone polarity in two Gur languages. SLS 18(1): 77-103.

Kiparsky, P. 1994. Allomorphy or morphophonology? In R. Singh (ed.), Trubetzkoy's Orphan. Current Issues in Linguistic Theory 144, 13-31.

Leben, W. 1973. Suprasegmental Phonology. PhD dissertation, MIT, Cambridge, Mass.

Lieber, R. 1982. Allomorphy. Linguistic Analysis 10(1): 27-52.

McCarhty, J. \& A. Prince. 1993. Generalized Alignment. Ms., University of Massachusetts, Amherst and Rutgers University.

McCarthy, J. 1986. OCP Effects: Gemination and antigemination. Linguistic Inquiry 17: 207-264.

Newman, P. 1995. Hausa tonology: Complexities in an "easy" tone language. In J. Goldsmith (ed.), The Handbook of Phonological Theory. Blackwell.

Odden, David. 1986. On the role of the Obligatory Contour Principle in phonological theory. Language 62(2): 353-382.

Picanço, G. 2002. Tones in Mundurukú Nouns. Ms., University of British Columbia.

Prince, A. \& P. Smolensky. 1993. Optimality Theory: Constraint Interaction in Generative Grammar. Ms., Rugters University and University of Colorado at Boulder.

Pulleyblank, D. 1986. Tone in Lexical Phonology. Reidel.

Pulleyblank, D. 1996. Neutral vowels in Optimality Theory: A comparison of Yoruba \& Wolof. Canadian Journal of Linguistics 41: 295-347.

Schuh, R.G. 1978. Tone rules. In V. Fromkin (ed.), Tone: A Linguistic Survey. Academic Press.

Smolensky, P. 1997. Constraint interaction in generative grammar II: Local conjunction, or random rules in universal grammar. Paper presented at Hopkins Optimality Theory Workshop/University of Maryland Mayfest, Baltimore MD.

Suzuki, K. 1998. A Typological Investigation of Dissimilation. PhD dissertation, University of Arizona.

Zwicky, A. 1986. The general case: basic form versus default form. Proceedings of the Annual Meeting of the Berkeley Linguistics Society, 305-314.

Department of Linguistics

Buchanan E-270 - 1866 Main Mall

Vancouver, BC, Canada - V6T-1Z1

University of British Columbia

globato@interchange.ubc.ca 